\title{
Style radzenia sobie ze stresem wśród ratowników medycznych i studentów ratownictwa medycznego
}

\section{Styles of coping with stress among paramedics and paramedic students}

\author{
Sylwia Jałtuszewska ${ }^{\bowtie}$, Monika Rut, Andrzej Rut, Kazimiera Hebel \\ Akademia Pomorska w Słupsku, Instytut Nauk o Zdrowiu, ul. Bohaterów Westerplatte 64, 76-200 Słupsk \\ $\triangle$ sjaltuszewska@wp.pl
}

\begin{abstract}
Introduction: Styles of coping with stress have preoccupied psychologists for several years, but also scientists representing other disciplines, particularly medicine, pedagogics and sociology. Employees of the State Emergency Medical Services are particularly exposed to emotional and physical stress. Paramedic students are trained in simulation rooms where they learn how to make rational decisions and receive occupational training in a real-life setting reflecting normal conditions of their future work. Certainly, all of these factors in combination give future paramedics an understanding of their profession.

The aim of the study was to evaluate styles of coping with stress and the level of exposure to stress among professionally active paramedics and paramedic students.

Materials and methods: The level of exposure to stress was evaluated with the PSS-10 test, and styles of coping with stress were identified using the CISS questionnaire.
\end{abstract}

Results: The study group involved $87(100 \%)$ respondents, of whom 29 (33.33\%) were paramedics working in the State Medical Rescue System, 29 (33\%) were first-degree paramedic students of the Pomeranian Academy in Słupsk, and 29 (33\%) were paramedic students of the 2-year course at the Private School for Adults and Adolescents. The mean age of respondents was 29.91 (SD $=7.75$ ). In relation to stress coping styles the highest mean scores were found for the task-oriented style. Among the professionally active paramedics work experience significantly influenced the level of stress and stress management styles $(\mathrm{p}=0.0000)$.

Conclusions: The task-oriented style of coping with stress predominated among paramedic students and professionally active paramedics.

Keywords: paramedic; student; style; stress.

\begin{abstract}
ABSTRAKT
Wstęp: Zagadnieniem stresu i sposobami radzenia sobie z nim od wielu lat zajmują się specjaliści psychologii oraz naukowcy z innych dziedzin, zwłaszcza medycyny, pedagogiki i socjologii. Państwowe Ratownictwo Medyczne jest strukturą szczególnie narażoną na obciążenia psychofizyczne i stres. Studenci i słuchacze kierunków ratownictwo medyczne do pracy zawodowej są przygotowywani w warunkach pracowni symulacyjnych, w których uczą się podejmowania racjonalnych decyzji, natomiast praktyki zawodowe odbywają w warunkach naturalnych, odzwierciedlających charakter przyszłej, niezwykle trudnej pracy.

Celem pracy była ocena natężenia poziomu stresu i sposobu radzenia sobie ze stresem w grupie czynnych zawodowo ratowników medycznych, studentów i słuchaczy ratownictwa medycznego. Materiały i metody: Do oceny poziomu stresu zastosowano test PSS-10, natomiast do oceny sposobów radzenia sobie ze stresem zastosowano kwestionariusz CISS pozwalający na określenie stylu radzenia sobie ze stresem.
\end{abstract}

Wyniki: Grupę badawczą stanowiło 87 (100\%) respondentów, wśród których było 29 (33,33\%) ratowników medycznych pracujący w Systemie Państwowego Ratownictwa Medycznego, 29 (33,33\%) studentów studiów pierwszego stopnia kierunku ratownictwo medyczne Akademii Pomorskiej w Słupsku oraz 29 (33,33\%) słuchaczy 2-letniego studium kierunku ratownictwo medyczne przy szkole Towarzystwa Edukacji Dorosłych i Młodzieży. Średnia wieku całej grupy oscylowała w granicach 29,91 $(\mathrm{SD}=7,75)$. W odniesieniu do stylów radzenia sobie ze stresem średnie najwyższe wartości we wszystkich grupach występowały w stylu skoncentrowanym na zadaniu. Wśród czynnych zawodowo ratowników medycznych staż pracy istotnie statystycznie wpływa na poziom stresu i style radzenia sobie ze stresem $(p=0,0000)$.

Wnioski: Styl skoncentrowany na zadaniu jest stylem radzenia sobie ze stresem zarówno wśród studentów i słuchaczy kierunku ratownictwo medyczne, jak i w grupie pracujących zawodowo ratowników medycznych.

Słowa kluczowe: ratownik medyczny; student; styl; stres.

\section{WSTĘP}

Zagadnieniem stresu i stylami radzenia sobie z nim od wielu lat zajmują się specjaliści psychologii oraz przedstawiciele innych dyscyplin, zwłaszcza medycyny, pedagogiki i socjologii.
Literatura naukowa przedstawia wiele sposobów radzenia sobie ze stresem, m.in. racjonalne myślenie, wysiłek fizyczny, korzystanie z metod relaksacji, choreoterapię, medytację i wiele innych. Wyodrębniono 3 sposoby radzenia sobie ze stresem. Są to style skoncentrowane na: zadaniu, emocjach 
i unikaniu [1, 2]. Ich skuteczność jest uzależniona od rodzaju stresora, czynników osobniczych oraz charakterologicznych danego człowieka. Zasadniczą kwestią jest odpowiedź na pytanie, czy podejmowany styl radzenia sobie ze stresem jest skuteczny?

Równie duże zainteresowanie naukowe i społeczne wzbudza występujący powszechnie stres. Na szczególną uwagę zasługuje fakt, iż wywołuje on nie tylko negatywne skutki, ale ma również pozytywne strony. Znanych jest wiele definicji, najczęściej jednak stres definiowany jest jako proces, w którym czynniki zewnętrzne narażają lub naruszają równowagę organizmu $[3,4,5]$.

Od kilku lat łatwiej dostępne są publikacje naukowe mówiące o stresie w służbach ratunkowych. Państwowa Straż Pożarna i Policja to współcześnie jednostki systemu mające najlepiej zorganizowaną pomoc psychologiczną świadczoną $\mathrm{w}$ formie indywidualnej bądź grupowej, podejmowaną w sytuacjach wydarzeń kryzysowych związanych z pracą.

Podstawową jednostką systemu ratownictwa zintegrowanego jest Państwowe Ratownictwo Medyczne, którego przedstawiciele, czyli wykonujący swój zawód ratownicy medyczni, są permanentnie narażeni na szczególnie duże obciążenia psychofizyczne pod postacią stresu nie tylko chronicznego, lecz także traumatycznego [6].

Środowisko zawodowe ratowników medycznych często podnosi temat niesienia pomocy psychologicznej, a szczególnie jej braku, natomiast instytucje prawodawcze oraz nadzoru niechętnie i sporadycznie podejmują ten temat. Obecna tendencja i dążenie do prywatyzacji tych służb niestety niosą ze sobą konsekwencje ponadnormatywnej liczby godzin pracy, przede wszystkim jednak minimalizuje szanse na zatrudnienie psychologa pomagającego ratownikom. Niepokojący jest także fakt, iż istnieje społeczne przekonanie, że osoby wykonujące zawód ratownika medycznego mają odpowiednie predyspozycje psychologiczne do wykonywania tego rodzaju pracy.

W grupie przyszłych studentów kierunku ratownictwo medyczne nie ma obowiązku wykonania testów psychologicznych czy oceny profilu osobowości pozwalających na weryfikację i wybór kandydatów z predyspozycjami do wykonywania tego zawodu. W grupie pracowników czynnych zawodowo także nie ma specjalistycznych badań zarówno tych wstępnych, jak i później tych okresowych. Ratownik medyczny w swojej pracy jest narażony na trudne sytuacje związane z obowiązkiem i odpowiedzialnością wynikającymi z ratowania zdrowia i życia człowieka. Stres jest także wynikiem działań podejmowanych w trudnych i szybko zmieniających się warunkach. Związany jest z koniecznością podejmowania decyzji i kierowania zespołem. Zawód ratownika medycznego nie jest zawodem regulowanym, nie ma także jednolitej struktury posiadającej przedstawicielstwo w postaci np. izb ratowników medycznych. Każda sytuacja stresogenna staje się więc indywidualnym problemem pracownika. Jeżeli wziąć pod uwagę odpowiedzialność prawną i etyczną za najwyższe wartości, jakimi są zdrowie i życie ludzkie, wówczas okaże się, że stres jest nieodłącznym czynnikiem charakteryzującym ten zawód.
Studenci i słuchacze kierunku ratownictwo medyczne w czasie studiów w warunkach pracowni symulacyjnych uczą się podejmowania trafnych decyzji w zależności od zmiany stanu klinicznego poszkodowanego. Praktyki zawodowe odbywające się w warunkach naturalnych dają wyobrażenie przyszłej pracy.

Reasumując, praca ratownika medycznego związana jest z ustawicznym narażeniem na czynniki stresogenne i w związku z tym wymaga zapewnienia możliwości korzystania ze stałej pomocy psychologicznej. Świadomość pracownika wykonującego zawód o wysokim narażeniu na stres nie wystarczy. Musi on wiedzieć, że z pomocą psychologa znajdzie własne, racjonalne sposoby na odreagowanie napięcia psychicznego.

Celem pracy była ocena natężenia poziomu stresu oraz weryfikacja sposobów radzenia sobie ze stresem w grupie ratowników medycznych, studentów i słuchaczy ratownictwa medycznego.

\section{MATERIAŁY I METODY}

Grupę badawczą stanowiło 87 (100\%) respondentów, z których 29 (33,33\%) osób to ratownicy medyczni pracujący w Systemie Państwowego Ratownictwa Medycznego, 29 (33,33\%) to studenci studiów pierwszego stopnia kierunku ratownictwo medyczne Akademii Pomorskiej w Słupsku oraz 29 $(33,33 \%)$ to słuchacze 2 -letniego studium kierunku ratownictwo medyczne przy szkole Towarzystwa Edukacji Dorosłych i Młodzieży. Kwestionariusze ankiet były anonimowe, a respondenci wyrazili zgodę na uczestnictwo w badaniach. Dla potrzeb niniejszej pracy badani zostali podzieleni na trzy grupy: student, ratownik oraz słuchacz. Badania zostały przeprowadzone na przełomie 2013 i $2014 \mathrm{r}$.

Do oceny sposobów radzenia sobie ze stresem zastosowano kwestionariusz radzenia sobie w sytuacjach stresowych (Coping Inventory for Stressful Situations - CISS) przełożony na polskie warunki przez Szczepaniak i wsp. Respondenci odpowiadali na 48 pytań zgodnie ze skalą umieszczoną w kwestionariuszu. CISS pozwala na określenie stylu radzenia sobie ze stresem w 3 skalach, tj.: SSZ - styl skoncentrowany na zadaniu, SSE - styl skoncentrowany na emocjach, SSU - styl skoncentrowany na unikaniu. Dla skali SSU można wyliczyć wynik z 2 podskal: ACZ - zaangażowanie w czynności zastępcze oraz PKT - poszukiwanie kontaktów towarzyskich. Surowym wynikiem tych skal jest suma punktów dla danego stylu. Minimalny wynik ze skali wynosi 16, a maksymalny 80 punktów [7].

Do oceny poziomu stresu zastosowano test PSS-10 (Perceived Stress Scale), który został zaadoptowany do polskich warunków przez Juczyńskiego i Ogińską-Bulik [8]. Kwestionariusz składa się z 10 pytań, na które ankietowani odpowiadali zgodnie ze skalą podaną w treści. Przed obliczeniem wyniku skali dokonano zmiany punktacji w sformułowanych pozytywnie pytaniach $\mathrm{nr}$ 4, 5, 7 i 8. Zgodnie z instrukcją dokonano zamiany punktacji wg zasady: $0=4,1=3,3=1$, $1=4$. Następnie wynik został przeliczony do skali stenowej, 
TABELA 1. Wynik skali PSS-10 w przeliczeniu do stenów [8]

\begin{tabular}{cc} 
Skala stenowa & Wynik skali \\
\hline 1 & 0 \\
\hline 2 & $1-3$ \\
\hline 3 & $4-9$ \\
\hline 4 & $10-13$ \\
\hline 5 & $14-16$ \\
\hline 6 & $17-19$ \\
\hline 7 & $20-22$ \\
\hline 8 & $23-26$ \\
\hline 9 & $27-30$ \\
\hline 10 & $31-40$ \\
\hline
\end{tabular}

zgodnie z zasadą przedstawioną w tabeli 1 [8]. Skala stenowa (standard ten) jest to skala testu psychologicznego znormalizowana tak, aby średnia w populacji wynosiła 5,5, a odchylenie standardowe 2 . W skali tej jest 10 jednostek [9].

Wynik w granicach 1-4 stena traktowany jest jako poziom niski, 5-6 stena jako przeciętny, natomiast 7-10 stena jako wysoki [8].

Dane zgromadzono w postaci bazy danych i wprowadzono do arkusza kalkulacyjnego MS Excel 2010. Z kolei statystyczne wyniki przeprowadzono za pomocą pakietu statystycznego Statistica PL v. 9.1. Wyliczono wartości średnie (M) i odchylenie standardowe (SD). Do wnioskowania istotności różnic pomiędzy średnimi zastosowano analizę wariancji ANOVA, z kolei dla zmiennych jakościowych test U Manna-Whitneya. Przyjęto wartość $\mathrm{p}=0,05$.

\section{WYNIKI}

\section{Dane socjodemograficzne badanych grup}

Średnia wieku całej grupy oscylowała w granicach 29,91 ( $\mathrm{SD}=7,75)$, minimalna wynosiła 21 lat, a maksymalna 54 lata. W grupie studentów średnia wieku wynosiła 26,38 (SD = 5,47), wśród ratowników 34,21 ( $S D=9,00)$, natomiast w grupie słuchaczy 29,14 (SD = 6,41). W grupie ratowników średnia stażu pracy oscylowała w granicach $8,45(\mathrm{SD}=5,91)$, gdzie minimalna wynosiła 1 rok, a maksymalna 22 lata.

W grupie studentów i ratowników w zdecydowanej większości byli mężczyźni, natomiast wśród słuchaczy większość stanowiły kobiety. Ponad połowa studentów i ratowników pochodziła z miasta, natomiast w grupie słuchaczy większość mieszkała na wsi (tab. 2).

TABELA 2. Dane demograficzne badanych grup

\begin{tabular}{lcccc}
\multirow{2}{*}{ Grupa } & Mężczyzna & Kobieta & Wieś & Miasto \\
\cline { 2 - 5 } & \multicolumn{4}{c}{$\mathbf{n}(\%)$} \\
\hline Student & $24(82,76)$ & $5(17,24)$ & $14(48,28)$ & $15(51,72)$ \\
\hline Ratownik & $23(79,31)$ & $6(20,69)$ & $9(31,03)$ & $20(68,97)$ \\
\hline Słuchacz & $10(34,28)$ & $19(65,52)$ & $15(51,72)$ & $14(48,28)$ \\
\hline Ogółem & $57(65,52)$ & $30(34,48)$ & $38(43,68)$ & $49(56,32)$ \\
\hline
\end{tabular}

TABELA 3. Wartości średnie skal radzenia sobie ze stresem w odniesieniu do badanych grup

\begin{tabular}{cccccc}
\multirow{2}{*}{ Grupa } & SSZ & SSE & SSU & ACZ & PKT \\
\cline { 2 - 6 } & \multicolumn{5}{c}{ średnia (SD) } \\
\hline \multirow{2}{*}{ Student } & 61,81 & 35,69 & 43,54 & 18,11 & 17,11 \\
& $(7,94)$ & $(9,47)$ & $(9,36)$ & $(6,52)$ & $(2,80)$ \\
\hline \multirow{2}{*}{ Ratownik } & 56,31 & 46,16 & 46,31 & 20,25 & 16,97 \\
& $(9,19)$ & $(11,12)$ & $(9,98)$ & $(5,99)$ & $(4,37)$ \\
\hline \multirow{2}{*}{ Stuchacz } & 54,45 & 39,62 & 44,38 & 19,45 & 16,34 \\
& $(9,06)$ & $(11,23)$ & $(11,03)$ & $(5,85)$ & $(4,26)$ \\
\hline
\end{tabular}

SSZ - styl skoncentrowany na zadaniu; SSE - styl skoncentrowany na emocjach; SSU - styl skoncentrowany na unikaniu; ACZ - zaangażowanie w czynności zastępcze; PKT - poszukiwanie kontaktów towarzyskich; SD - odchylenie standardowe

\section{Style radzenia sobie ze stresem}

W odniesieniu do stylów radzenia sobie ze stresem średnie najwyższe wartości we wszystkich grupach występowały w SSZ. Ratownicy medyczni w porównaniu ze studentami i słuchaczami prezentowali wyższe średnie wartości w SSE. Nieco wyższą średnią w stylu PKT prezentują studenci (tab. 3).

\section{Poziom stresu wśród badanych grup}

U ponad 50\% studentów dominuje niski poziom stresu, z kolei wśród połowy ratowników medycznych poziom przeciętny, natomiast u 75\% słuchaczy występuje wysoki poziom stresu (ryc. 1).

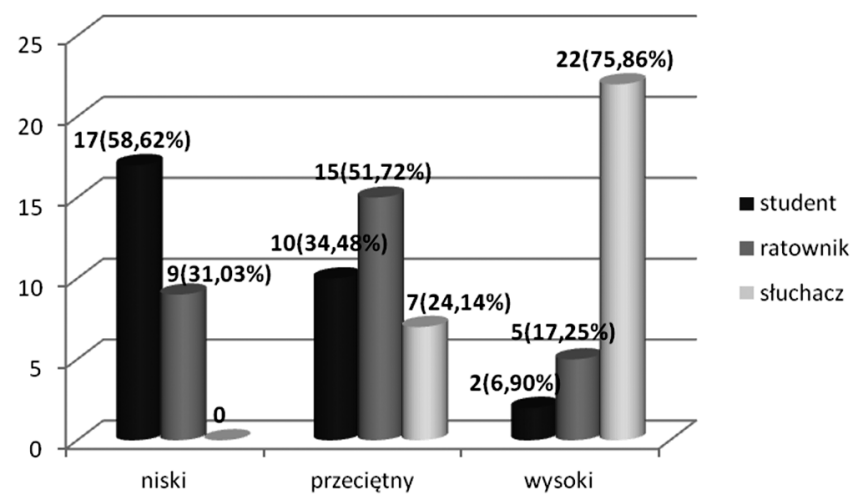

RYCINA 1. Poziom stresu w odniesieniu do liczby respondentów w badanych grupach

\section{Analiza statystyczna}

Na podstawie badań wykazano brak zależności istotnej statystycznie pomiędzy stylami radzenia sobie ze stresem a badanymi grupami $(p>0,05)$, natomiast zaobserwowano zależność istotną pomiędzy badanymi grupami a poziomem stresu $(\mathrm{p}=0,0000)$.

Analizując dane, wykazano zależność istotną statystycznie zmiennej dotyczącej płci tylko w odniesieniu do SSZ (test U Manna-Whitneya; p = 0,0404). Grupa mężczyzn częściej radziła sobie ze stresem przez podejmowanie zadania służącego rozwiązaniu danego problemu (SSZ - średnia 58,81; $\mathrm{SD}=8,84$ ) w porównaniu z kobietami (SSZ - średnia 54,53; $\mathrm{SD}=9,39)$ - rycina 2 . 


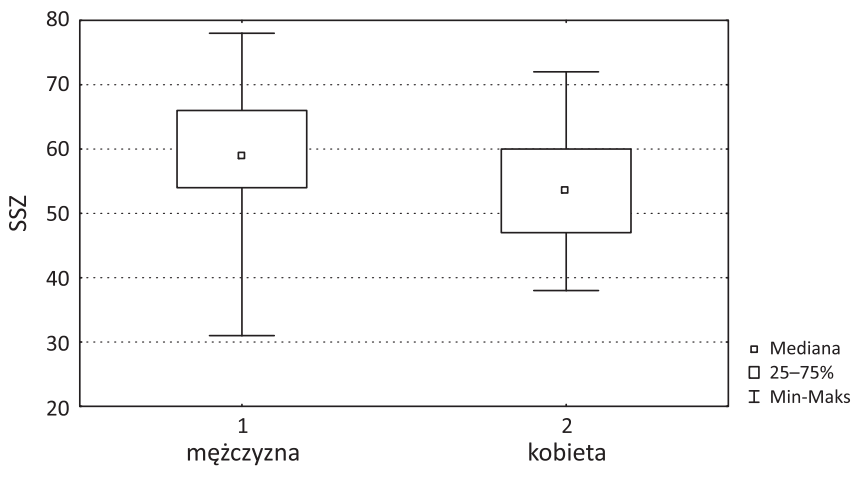

RYCINA 2. Zmienna dotycząca ptci w odniesieniu do stylu radzenia sobie ze stresem - skoncentrowany na zadaniu (SSZ)

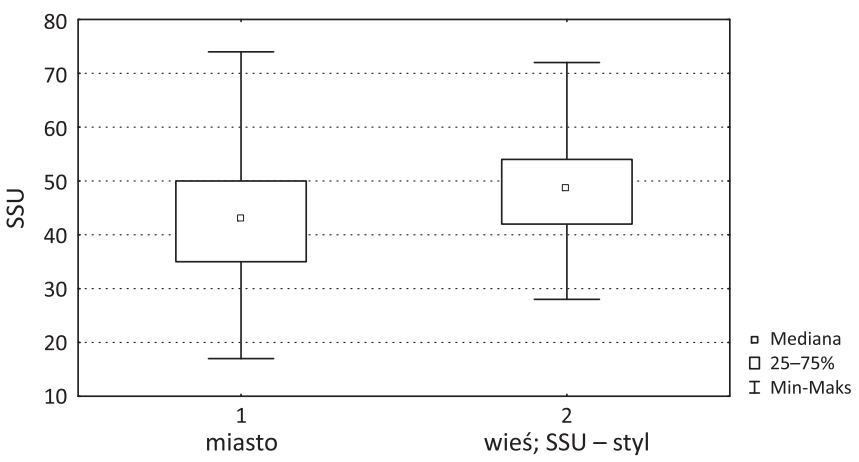

RYCINA 3. Zmienna dotycząca miejsca zamieszkania w odniesieniu do stylu radzenia sobie ze stresem - skoncentrowany na unikaniu (SSU)

Miejsce zamieszkania ma istotny statystycznie wpływ na SSU (test U Manna-Whitneya; $p=0,0210$ ). W sytuacji stresu wystrzeganie się myślenia, przeżywania i doświadczania sytuacji trudnych częściej wybierają respondenci mieszkający na wsi (SSU - średnia 47,50; SD = 9,02) w porównaniu z mieszkańcami miast (SSU - średnia 42,77; SD = 10,52) - rycina 3.

Wśród ratowników medycznych staż pracy wpływa istotnie statystycznie na poziom stresu i wszystkie style radzenia sobie ze stresem $(p=0,0000)$.

Analiza zależności pomiędzy kategoriami stresu a stylami radzenia sobie ze stresem wykazała wpływ istotny statystycznie tylko w odniesieniu do SSZ i SSE. Przeciętny i wysoki poziom stresu wpływa istotnie na SSZ, natomiast w SSE zależność występuje w odniesieniu do przeciętnego poziom stresu (tab. 4).

Badania wykazały brak zależności statystycznej pomiędzy wiekiem respondentów a poziomem stresu oraz stylami radzenia sobie ze stresem (test U Manna-Whitneya; $p$ > 0,05).

TABELA 4. Zależność pomiędzy poziomem stresu a stylami radzenia sobie ze stresem

\begin{tabular}{lcccc}
\multirow{2}{*}{$\begin{array}{c}\text { Skala } \\
\text { potrzeb }\end{array}$} & \multicolumn{3}{c}{ Poziom stresu } & Różnica NIR* \\
$\mathbf{n y y y}<<0,05$
\end{tabular}

* test post-hoc NIR - podano jedynie informacje o różnicach istotnych statystycznie; SSZ - styl skoncentrowany na zadaniu; SSE - styl skoncentrowany na emocjach

\section{DYSKUSJA}

Wybór najefektywniejszych metod radzenia sobie ze stresem oraz aktywne działanie są najbardziej pożądane w każdej grupie społecznej i wydają się najmniej obciążające psychikę, ale i również fizjologię człowieka.

Otrzymane wyniki badań wskazują, iż występuje istotna zależność pomiędzy badanymi grupami a poziomem stresu. Staż pracy wśród ratowników medycznych wpływa istotnie na poziom stresu oraz style radzenia sobie w sytuacjach stresowych. Wyniki te potwierdzają badania przeprowadzone przez Nowakowską i wsp. wśród pracujących zawodowo ratowników oraz studentów. Studenci ratownictwa radzą sobie ze stresem stylem skoncentrowanym na unikaniu, natomiast ratownicy medyczni koncentrują się na zadaniu. Powyższe wyniki różnią się od badań własnych, gdyż obie grupy preferują styl skoncentrowany na zadaniu. Nowakowska i wsp. objęli badaniem grupę składającą się ze 148 osób, z czego 66 było studentami ratownictwa medycznego w Łodzi. Można więc ostrożnie przypuszczać, iż wielkość miasta oraz rodzaj uczelni mają wpływ na wyniki [10]. Badania przeprowadzone przez Ślusarską i wsp. na grupie 98 ratowników medycznych również wykazały, iż poziom stresu oscyluje w granicach wartości przeciętnych, co również potwierdzono w badaniach własnych [11].

W odniesieniu do stylu radzenia sobie ze stresem grupy z badań własnych uzyskały najwyższe wyniki w stylu skoncentrowanym na zadaniu, co wydaje się dość oczywistym faktem ze względu na rodzaj wykonywanych czynności i pokonywanie trudności sytuacyjnych. Podobne wyniki uzyskali Bartczak i Bartczak w badaniu studentów dziennych i zaocznych studiów na kierunku ratownictwo medyczne oraz personelu medycznego Szpitalnego Oddziału Ratunkowego [12].

W badaniach własnych pracujący ratownicy medyczni wyrazili przeciętny poziom stresu oraz styl zadaniowy w radzeniu sobie ze stresem. Wyniki te są dość optymistyczne, ponieważ dobrze jest, gdy w zawodzie tak obciążającym psychicznie pracują osoby odporne na stres, a styl zadaniowy jest odpowiednim stylem do rodzaju wykonywanych czynności. Changa i wsp. w swoich badaniach stwierdzili, że styl zadaniowy jest związany z lepszym stanem zdrowia psychicznego, z kolei styl emocjonalny koreluje z gorszym samopoczuciem psychicznym [13].

Wśród słuchaczy 2-letniego Studium Ratownictwa Medycznego ponad $75 \%$ badanych wyraziło wysoki poziom stresu, a w tej grupie badanych ponad 60\% stanowiły kobiety. Można wnioskować, że płeć mogła mieć wpływ na taką wartość poziomu stresu oraz że kobiety w mniejszym stopniu są odporne na czynniki stresogenne związane z pracą w służbach ratunkowych. W literaturze brakuje badań z udziałem słuchaczy 2-letniej Szkoły Ratownictwa Medycznego, co może być związane z naborem słuchaczy, który na taki tok kształcenia był możliwy tylko do $2012 \mathrm{r}$.

Reasumując, pomimo takich optymistycznych wyników w odniesieniu do stylów radzenia sobie ze stresem oraz poziomu stresu bezsprzeczny jest fakt konieczności posiadania psychologa w strukturach służb ratunkowych. Obecnie 
ratownicy medyczni mają ograniczony dostęp do pomocy psychologicznej w takim zakresie, w jakim by oczekiwali. Obecni studenci i słuchacze mają świadomość wyboru obciążającego psychicznie zawodu, a tok studiowania przygotowuje ich do wykonywania ciężkiej pracy związanej z występowaniem różnych trudnych sytuacji oraz do rozwiązywania pojawiających się problemów.

\section{WNIOSKI}

Styl radzenia sobie ze stresem skoncentrowany na zadaniu jest odpowiednim stylem wśród studentów i słuchaczy kierunku ratownictwo medyczne oraz pracujących zawodowo ratowników medycznych. Poziom stresu wśród studentów przeważał w granicach wartości niskich, natomiast w zdecydowanej większości wśród słuchaczy w granicach wartości wysokich. Ratownicy medyczni oscylowali w granicach wartości przeciętnych. Poziom stresu wpływa istotnie statystycznie na styl radzenia sobie ze stresem skoncentrowanym na zadaniu i emocjach.

\section{PIŚMIENNICTWO}

1. Steciwko A, Mastalerz-Migas A. Definicja stresu oraz wpływ przewlekłych sytuacji stresowych na stan zdrowia człowieka. In: Rola psychologa i psychiatry w radzeniu sobie ze stresem przewlekłym. Wrocław: Wydawnictwo Urban \& Partner; 2012. p. 14-8.
2. Heszen-Niejodek I. Konteksty stresu psychologicznego. Katowice: Wydawnictwo Uniwersytetu Śląskiego; 2002. p. 22-4.

3. Grygorczuk A. Pojęcie stresu w medycynie i psychologii. Psychiatria 2008;5:111-5.

4. Steciwko A, Mastalerz-Migas A. Definicja stresu oraz wpływ przewlekłych sytuacji stresowych na stan zdrowia człowieka. In: Stres oraz wypalenie zawodowe. Wrocław: Wydawnictwo Urban \& Partner; 2012. p. 5.

5. Heszen I. Psychologia stresu. Warszawa: Wydawnictwo Naukowe PWN; 2014.

6. Ogińska-Bulik N, Kaflik-Pieróg M. Stres zawodowy w służbach ratowniczych. Łódź: Wydawnictwo Wyższej Szkoły Humanistyczno-Ekonomicznej w Łodzi; 2007. p. 37-8.

7. Strelau J, Jaworowska A, Wrześniewski K., Szczepaniak P. Podręcznik CiSS - Kwestionariusz Radzenia Sobie w Sytuacjach Stresowych. Warszawa: Pracownia Testów Psychologicznych Polskiego Towarzystwa Psychologicznego; 2005.

8. Juczyński Z, Ogińska-Bulik N. Narzędzia pomiaru stresu i radzenia sobie ze stresem. Warszawa: Pracownia Testów Psychologicznych Polskiego Towarzystwa Psychologicznego; 2009.

9. Hornowska E. Testy psychologiczne: teoria i praktyka. Warszawa: Wydawnictwo Scholar; 2007. p. 136.

10. Nowakowska K, Jabłkowska-Górecka K, Borkowska A. Style radzenia sobie ze stresem i zespół wypalenia zawodowego u studentów ratownictwa medycznego i ratowników medycznych. Psychiatr Psychol Klin 2009;9(4):242-8.

11. Ślusarska B, Nowicki G, Jędrzejewicz D. Poziom odczuwanego stresu i czynniki stresogenne na stanowisku pracy ratownika medycznego. Pielęg XXI w 2014;1(46):11-8.

12. Bartczak M, Bartczak M. Natężenie stresu i sposoby radzenia sobie ze stresem u ratowników medycznych i studentów ratownictwa medycznego. Rocznik Naukowy Kujawsko-Pomorskiej Szkoły Wyższej w Bydgoszczy. Nauki o Edukcaji 2009;5:7-17.

13. Chang EM, Bidewell JW, Hungtington AD, Daly J, Johnson A, Wilson H, et. al. A survey of role stress, coping and health in Australian and New Zealand hospital nurses. Int J Nurs Stud 2007;44(8):1354-62. 